\title{
Diazepam Potentiates the Corticoidogenic Response of Bovine Adrenal Fasciculata Cells to Dibutyryl Cyclic AMP
}

\author{
Kazutoshi YANAGIBASHI, Yuji OHNO, Noboru NAKAMICHI, \\ Takashi MATSUI, Keiko HAYASHIDA, Mitsuyuki TAKAMURA, \\ Kenji YAMADA, Shohei TOU and Masahiro KAWAMURA
}

Department of Pharmacology I, The Jikei University School of Medicine. 3-25-8. Nishi-shinbashi. Minato-ku. Tokyo 105, Japan

Accepted July 27, 1989

\begin{abstract}
To provide a possible role of peripheral type benzodiazepine receptors in the regulation of glucocorticoid biosynthesis. We have examined the effect of diazepam on the corticoidogenic response to dibutyryl cyclic AMP in isolated bovine adrenal fasciculata cells. Diazepam alone (up to $100 \mu \mathrm{M}$ ) had no effect on the corticoidogenesis. Diazepam caused a dose-dependent potentiation of dibutyryl cyclic AMP-induced corticoidogenesis. However, diazepam had no effect on the corticoidogenic response to $\mathrm{ACTH}$ and a high concentration of $\mathrm{KCl}$. The potentiating effect by diazepam was clearly detected after 90 min-incubation, and it was blocked by YM-684 (diazepam antagonist) and ML-236B (cholesterol de novo synthesis inhibitor). Diazepam caused no significant decrease of intracellular content of cholesteryl esters during the corticoidogenic response to dibutyryl cyclic AMP. When the cells were incubated in the presence of $(+)$-PN200-110, a potent voltage-dependent $\mathrm{Ca}$ channel inhibitor, the potentiating effect by diazepam was not affected in spite of a significant inhibition of dibutyryl cyclic AMP-induced corticoidogenesis. These results indicate that the potentiating effect of diazepam on dibutyryl cyclic AMP-induced corticoidogenesis is due in part to the activation of the intracellular cholesterol supply system (cholesterol de novo synthesis) without any change of voltage-dependent $\mathrm{Ca}$ channels.
\end{abstract}

It has been established that benzodiazepines, anxiolytic and anticonvulsant drugs, bind to at least two classes of binding sites termed central and peripheral type benzodiazepine receptors, respectively $(1,2)$. Central type benzodiazepine receptors are closely linked to GABA receptors (3-5) and modulate the GABA-regulated chloride channels (6-8). in contrast, peripheral type benzodiazepine receptors are not linked to GABA-receptors $(9,10)$. These receptors have been identified in many peripheral tissues (11-13), in which the greatest receptor density is observed in the adrenal cortex $(11,13)$. However, the precise physiological function of these peripheral receptors is still not clear. Shibata et al. demonstrated that the prototypic benzodiazepine diazepam inhibited potassium-induced aldosterone secretion in adrenal glomerulosa cells by acting on voltage-dependent $\mathrm{Ca}$ channels (14). Recently, we reported the purification of a novel protein from bovine adrenal cortex that is rapidly synthesized by ACTH in a dosedependent manner and plays an essential role during the corticoidogenic response of adrenal fasciculata cells $(15,16)$, (K. Yanagibashi et al., unpublished data). Structural analysis of this protein reveals identity to the endogenous benzodiazepine-like substance (endozepine) from bovine brain (17) except the loss of two amino acids from the carboxy terminus (18). These observations suggest the possibility that peripheral type benzodiazepine receptors may also play an important role in the regulation of glucocorticoid biosynthesis in adrenal fasciculata cells.

In the present study, we have examined whether or not diazepam, a potent agonist to 
peripheral type benzodiazepine receptors, modulates the corticoidogenic response to dibutyryl cyclic AMP ( $\mathrm{Bt}_{2} \mathrm{CAMP}$ ) in bovine adrenal fasciculata cells. Our results demonstrate that peripheral type benzodiazepine receptors are indeed involved in the potentiating action of diazepam on $\mathrm{Bt}_{2} \mathrm{CAMP}$-induced corticoidogenesis.

\section{Materials and Methods}

Preparation of dispersed bovine fasciculata cells: Bovine adrenocortical fasciculata cells were prepared by tryptic digestion by the method described previously $(19,20)$.

Incubation: The cell suspensions (approximately $10^{5}$ cells per each incubation volume of $0.5 \mathrm{ml}$ ) were incubated at $37^{\circ} \mathrm{C}$ under $95 \% \mathrm{O}_{2}-5 \% \mathrm{CO}_{2}$ as the gas phase with or without test substances. Incubation was routinely continued for 1 to $3 \mathrm{hr}$ in a dark room. Diazepam and (+)-PN200-110 were dissolved in ethanol, and other chemicals were dissolved in the ordinary buffer for cell suspensions as described elsewhere $(19,20)$. The final concentration of ethanol in the incubation medium was less than $0.2 \%$, a concentration which was shown to exert no demonstrable effect on corticoidogenesis.

Analytical methods: Corticoids were extracted from whole cell suspensions with dichloromethane and measured fluorometrically by the method of Silber et al. using cortisol as the standard (21). Cellular free cholesterol and cholesteryl esters were assayed by the enzymatic method of Gamble et al. (22).

Chemicals: The sources of the various chemicals employed in this study were as fol-

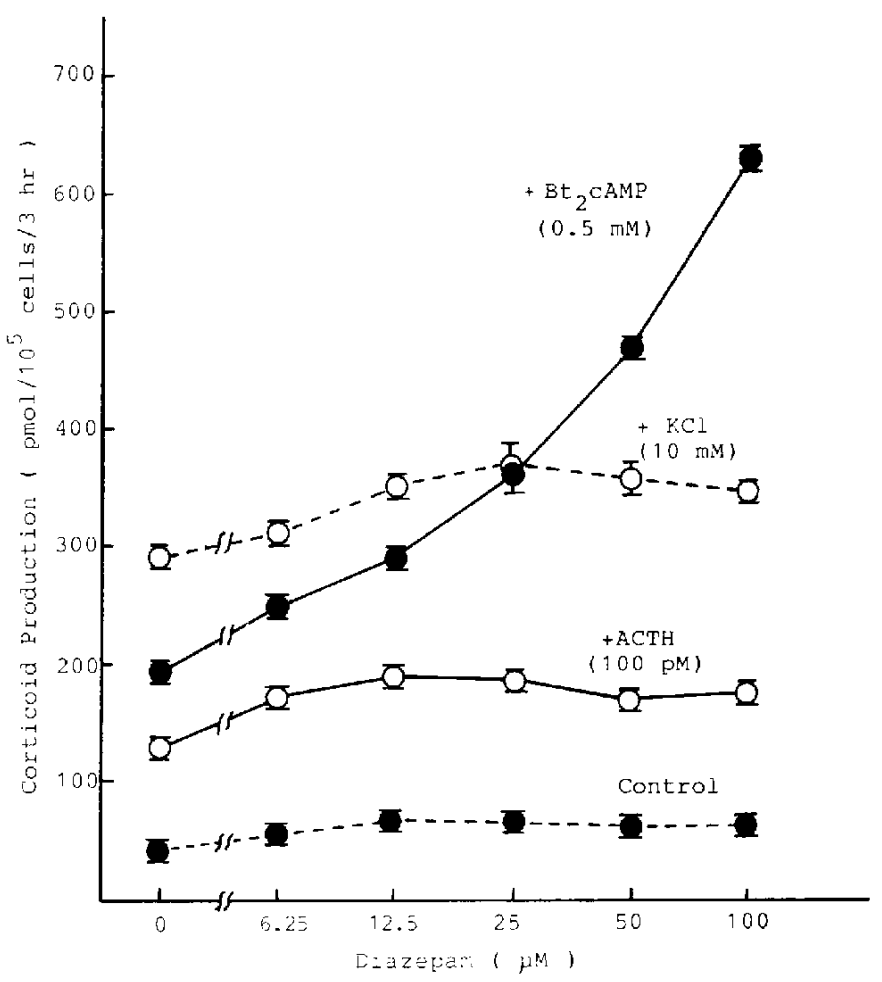

Fig. 1. Effect of diazepam on the corticoidogenic response to $\mathrm{Bt}_{2} \mathrm{CAMP}, \mathrm{KCl}$ and $\mathrm{ACTH}$. Dispersed cells prepared from bovine adrenal fasciculata were preincubated at $37^{\circ} \mathrm{C}$ for 10 min with the indicated concentrations of diazepam, and the reaction was started by adding the steroidogenic agents shown. The concentrations of the agents used were $0.5 \mathrm{mM} \mathrm{Bt} \mathrm{m}_{2} \mathrm{CAMP}, 10 \mathrm{mM} \mathrm{KCl}$ and $100 \mathrm{pM} \mathrm{ACTH}$. After 3 hr-incubation, corticoids were extracted with dichloromethane from the cell suspensions and estimated fluorometrically. Values are the meantS.E. of triplicate determinations. 
lows: Dibutyryl cyclic AMP $\left(\mathrm{N}^{6}, 2^{\circ}-\mathrm{O}\right.$ dibutyryladenosine $\quad 3^{\prime}, 5^{\prime}$-cyclicmonophosphate) was from Sigma Chemical Co.; Diazepam was from Wako Pure Chemical Industry, Japan: (+)-PN200-110 was kindly donated by Drs. R. Viret and F. Mitterhofer (Sandoz); ML-236B and YM-684 (Ro 151788) were gifts from Sankyo Co., Japan and Yamanouchi Pharmaceutical Co., Japan, respectively. All other chemicals were reagent grade or better.

\section{Results}

Effect of diazepam on the corticoidogenic response of bovine adrenocortical cells to $\mathrm{Bt}_{2}$ cAMP, $\mathrm{KCl}$ and ACTH: As shown in Fig. 1. diazepam potentiated the $\mathrm{Bt}_{2} \mathrm{CAMP}$-induced corticoidogenesis in a dose-dependent man- ner, but was without effect on the corticoidogenesis induced by either ACTH (100 $\mathrm{pM})$ or a high concentration of $\mathrm{KCl}(10 \mathrm{mM})$. In the absence of steroidogenic agents, no effect by diazepam alone (up to $100 \mu \mathrm{M}$ ) on the corticoidogenesis was observed in these experiments.

Effect of diazepam on $\mathrm{Bt}_{2} \mathrm{CAMP}$-induced corticoidogenesis: It can be seen from Fig. 2 that diazepam $(100 \mu \mathrm{M})$ potentiates the dosedependent stimulation of the corticoidogenic response to $\mathrm{Bt}_{2} \mathrm{CAMP}$ in bovine adrenal fasciculata cells.

Figure 3 shows the time-course of the corticoidogenic response to $0.5 \mathrm{mM} \mathrm{Bt}_{2} \mathrm{CAMP}$ with or without $100 \mu \mathrm{M}$ diazepam. $\mathrm{Bt}_{2} \mathrm{CAMP}$ caused a linear increment of the corticoid production until $90 \mathrm{~min}$, and after then, the $\mathrm{Bt}_{2}-$

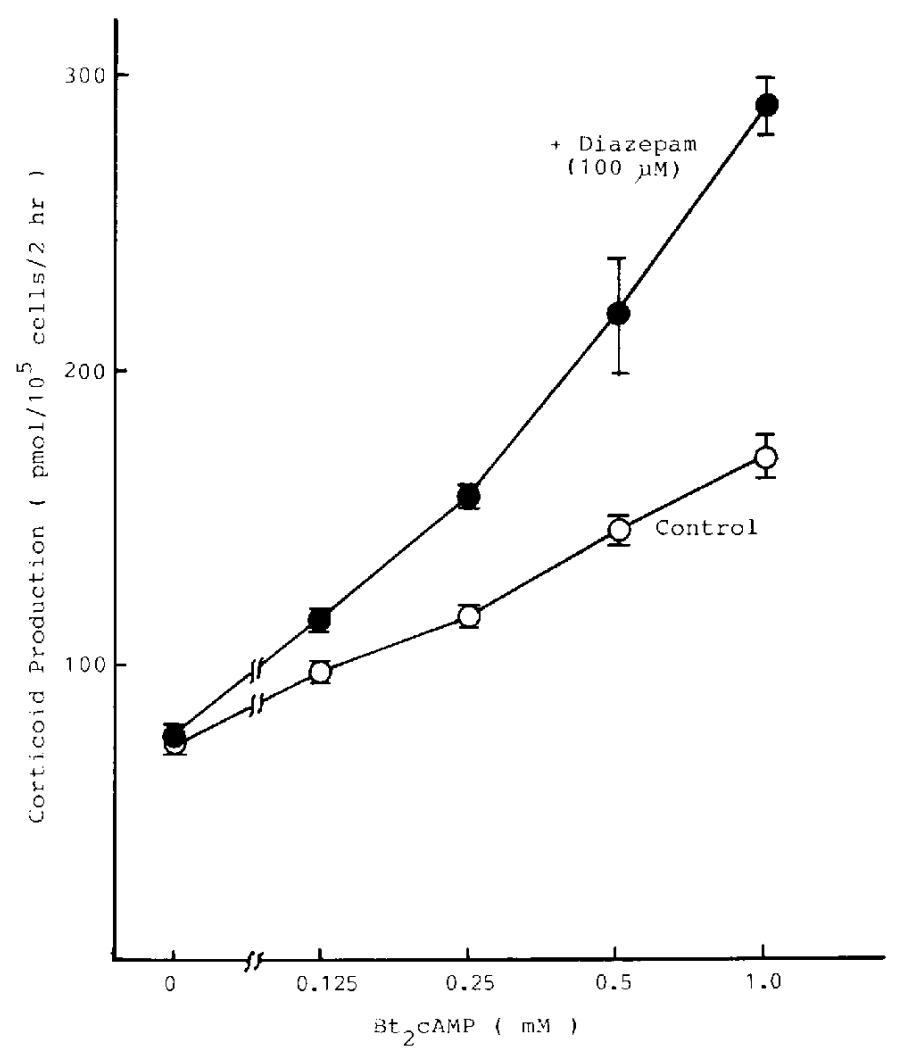

Fig. 2. Effect of diazepam on $\mathrm{Bt}_{2} \mathrm{CAMP}$-induced corticoidogenesis. Fasciculata cells were preincubated at $37^{\circ} \mathrm{C}$ for $10 \mathrm{~min}$ with $(O)$ ar without $(\mathrm{O})$ diazepam $(100 \mu \mathrm{M})$. and this was followed by a 2 hr-incubation with $\mathrm{Bt}_{2} \mathrm{CAMP}$ (indicated concentrations). After incubation, corticoids were extracted with dichloromethane from cell suspensions and estimated fluorometrically. Each value represents the mean $\pm S$.E. of triplicate determinations of two separate experiments. 


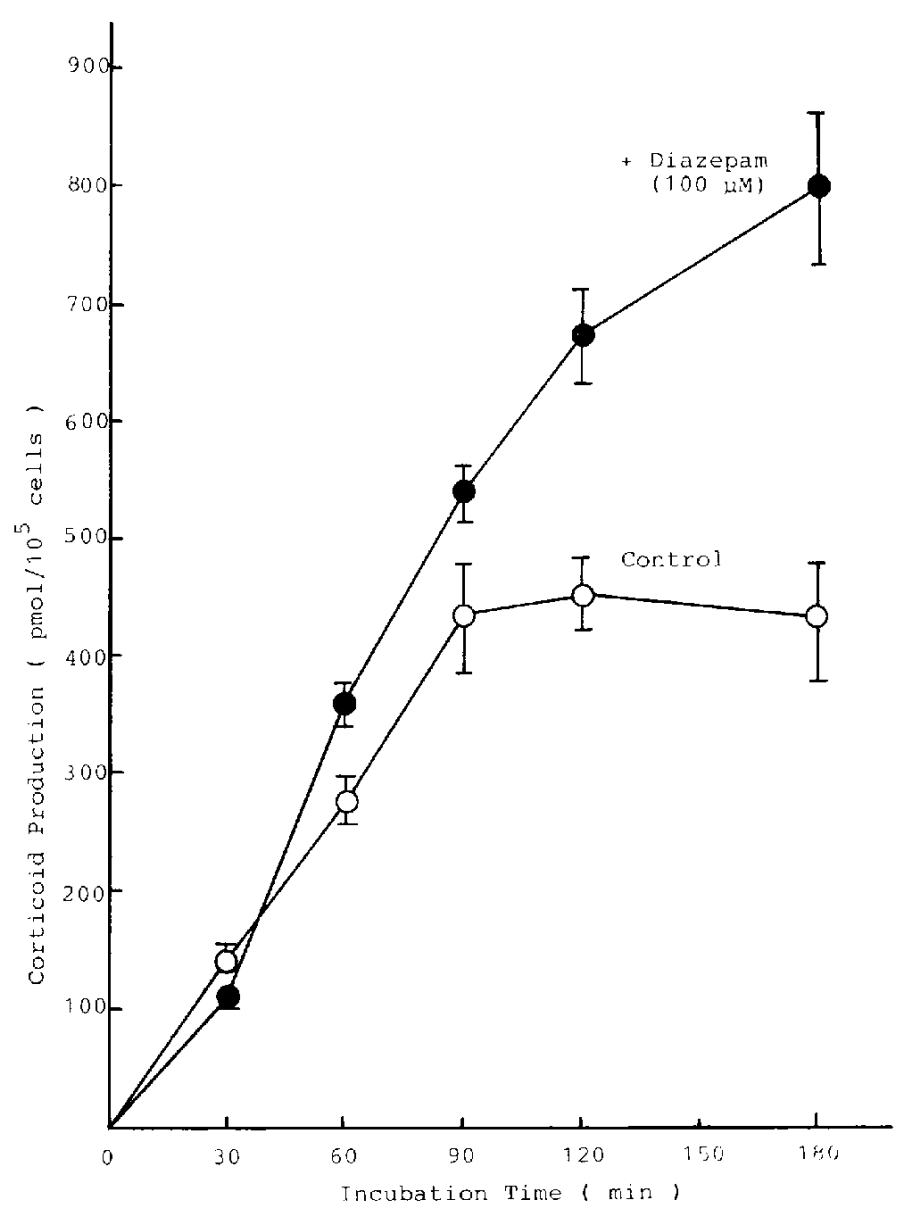

Fig. 3. Time-course of corticoidogenic response to $\mathrm{Bt}_{2} \mathrm{cAMP}$ with or without diazepam. Fasciculata cells were preincubated at $37^{\circ} \mathrm{C}$ for $10 \mathrm{~min}$ with (O) or without (O) $100 \mu \mathrm{M}$ diazepam, and the reaction was started by adding $0.5 \mathrm{mM} \mathrm{Bt}{ }_{2} \mathrm{CAMP}$. Samples of cell suspensions were taken at the indicated time for determination of corticoids. Values are the mean $\pm S . E$. of triplicate determinations of two separate experiments.

cAMP-induced corticoidogenesis was prevented. However, in the presence of $100 \mu \mathrm{M}$ diazepam, the corticoidogenic response to $\mathrm{Bt}_{2} \mathrm{CAMP}$ continued to increase even after 90 min incubation.

Effect of diazepam on intracellular content of cholesteryl esters: Figure 4 shows that diazepam $(100 \mu \mathrm{M})$ does not cause a significant decrease of intracellular content of cholesteryl esters under the same experimental condition as shown in Fig. 3. Similarly, no significant difference of the free cholesteral content was observed in the presence or $a b$ sence of diazepam (data not shown).

Influence of several antagonists on poten- tiating effect of diazepam: The experiments shown in Fig. 5 were designed to examine whether or not the potentiation by diazepam on $\mathrm{Bt}_{2} \mathrm{CAMP}$-induced corticoidogenesis is due to the interaction of diazepam with its specific receptor. The potentiating effect by diazepam is blocked by YM-684, a diazepam receptor antagonist (23).

ML-236B is known to be potent inhibitor of 3-hydroxy-3-methylglutaryl coenzyme $A$ reductase ( $\mathrm{HMG}-\mathrm{COA}$ reductase). which is the rate limiting enzyme in cholesterol de novo synthesis (24). As shown in Fig. 6, this inhibitor abolished the potentiating effect of diazepam on $\mathrm{Bt}_{2} \mathrm{CAMP}$-induced corticoido- 


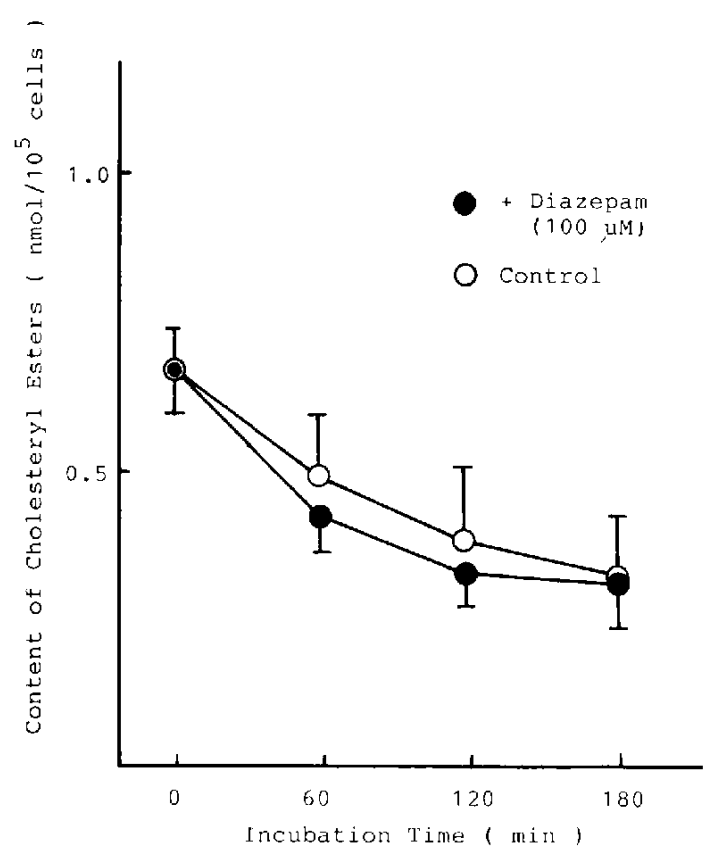

Fig. 4. Effect of diazepam on in tracellular content of cholesteryl esters during $\mathrm{Bt}_{2} \mathrm{CAMP}$-induced corticoidogenesis. Fasciculata cells were preincubated at $37^{\circ} \mathrm{C}$ for $10 \mathrm{~min}$ with (O) or without (O) $100 \mu \mathrm{M}$ diazepam, and the reaction was started by adding $0.5 \mathrm{mM} \mathrm{Bt}{ }_{2} \mathrm{CAMP}$. Samples of cell suspensions were taken at the indicated time for determination of cholesteryl esters as described under "Materials and Methods". Values are the mean \pm S.E. of triplicate determinations of three separate experiments.

\section{genesis.}

When the cells were incubated with $(+)$ PN200-110. a potent inhibitor of voltagedependent $\mathrm{Ca}$ channels (25). Bt $\mathrm{Bt}_{2} \mathrm{CAMP}$ induced corticoidogenesis was inhibited in a dose-dependent manner. However, as shown in Fig. 7, the potentiation by diazepam was not affected by this antagonist.

\section{Discussion}

In the present study, we have investigated the possible role of peripheral type benzodiazepine receptors in the regulation of adrenal glucocorticoid synthesis. Although the tissue distribution and biochemical properties of the peripheral type receptor have been examined, the precise physiological function of this receptor has not yet been elucidated. Peripheral type benzodiazepine receptors have

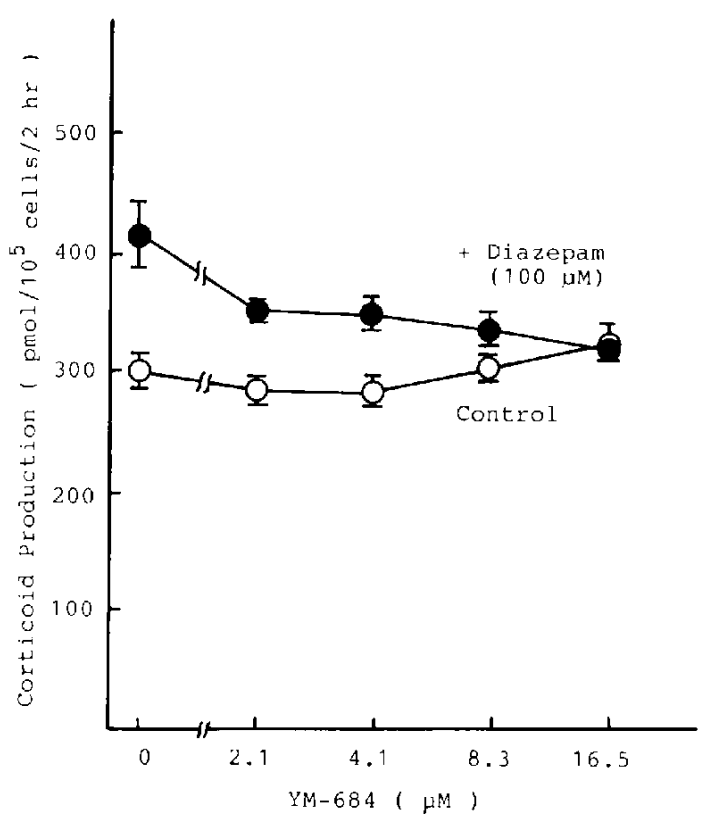

Fig. 5. Effect of $Y M-684$ on the potentiating effect of diazepam during corticoidogenic response to 0.5 $\mathrm{mM} \mathrm{Bt}{ }_{2} \mathrm{CAMP}$. Fasciculata cells were preincubated at $37^{\circ} \mathrm{C}$ for $10 \mathrm{~min}$ with $(\mathcal{O})$ or without $(O)$ diazepam $(100 \mu \mathrm{M})$ and $Y M-684$ (indicated concentrations), and the reaction was started by adding $0.5 \mathrm{mM} \mathrm{Bt}_{2}$ CAMP. Corticoids were extracted with dichloromethane from the cell suspensions after a $2 \mathrm{hr}$ incubation and measured fluorometrically. Each value represents the mean $\pm S$.E. of triplicate determinations of two separate experiments.

been distinguished according to their ligand specificities $(1,26)$. Certain benzodiazepines (e.g., Ro 5-4864 and PK11195) are high affinity ligands for the peripheral type benzodiazepine receptor $(11-13)$, but have no pharmacological activity in the modulation of the $\mathrm{GABA}_{\mathrm{A}}$-regulated chloride channels linked to central type benzodiazepine receptor $(9,10)$. By using $\left[{ }^{3} \mathrm{H}\right]$ Ro $5-4864$, peripheral type benzodiazepine receptors have been detected in a number of tissues. especially in the adrenal cortex (13). The binding of these specific ligands is displaced by dihydropyridine calcium channel blockers, suggesting that one of the possible functions of the peripheral type receptor is to be coupled to voltage-dependent calcium channels (2729). In adrenal glomerulosa cells, Shibata et al. reported that peripheral type benzodiaze- 


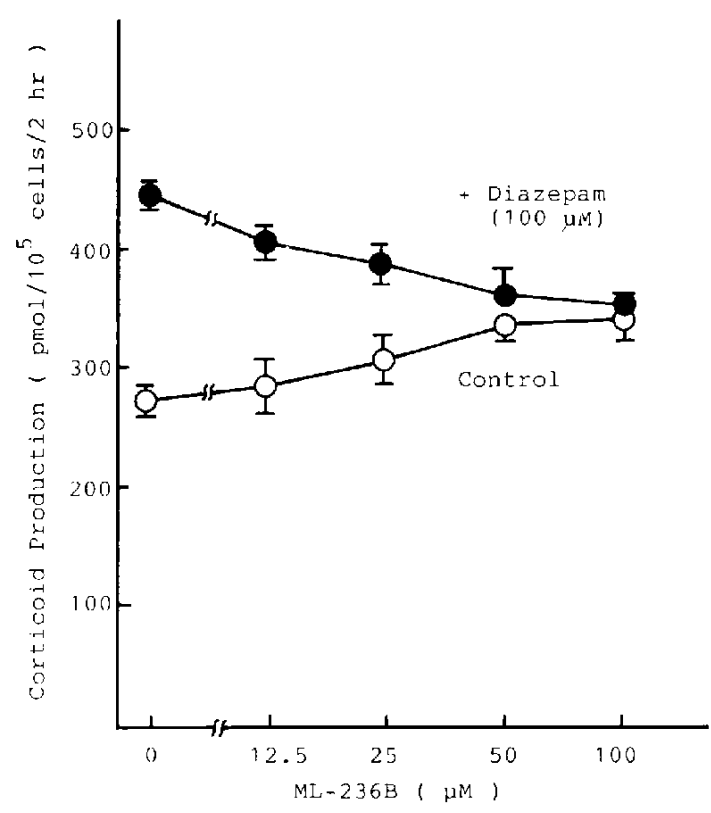

Fig. 6. Effect of ML-236B on the potentiating effect of diazepam during corticoidogenic response to 0.5 $\mathrm{mM} \mathrm{Bt}{ }_{2} \mathrm{CAMP}$. Fasciculata cells were preincubated at $37^{\circ} \mathrm{C}$ for $10 \mathrm{~min}$ with $(\mathbf{)})$ or without $(\mathrm{O})$ diazepam $(100 \mu \mathrm{M})$ and $\mathrm{ML}-236 \mathrm{~B}$ (indicated concentrations). and the reaction was started by adding $0.5 \mathrm{mM}$ $\mathrm{Bt}_{2} \mathrm{CAMP}$. Corticoids were extracted with dichloromethane from the cell suspensions after a $2 \mathrm{hr}$ incubation and measured fluorometrically. Each value represents the mean $\pm S$.E. of triplicate determinations of two separate experiments.

pine receptors have an inhibitory role in the regulation of aldosterone synthesis by interacting with voltage-dependent calcium channels (14). However, the experiments shown in Fig. 7 indicate that in adrenal fasciculata cells, voltage-dependent calcium channels are not involved in the potentiating effect of diazepam on $\mathrm{Bt}_{2} \mathrm{CAMP}$-induced corticoidogenesis.

It is obscure at present why diazepam is not able to potentiate the corticoidogenic responses to ACTH and $\mathrm{KCl}$ as shown in Fig. 1. However, a possible explanation for these discrepancies is as follows: Especially in "bovine" adrenal fasciculata cells, either 100 pM ACTH or $10 \mathrm{mM} \mathrm{KCl}$ appears to stimulate corticoidogenesis via a mechanism dependent on calcium ions but not on cyclic AMP (19, 20). Indeed, ACTH (100 pM) increases an intracellular cyclic AMP also in the "bovine"

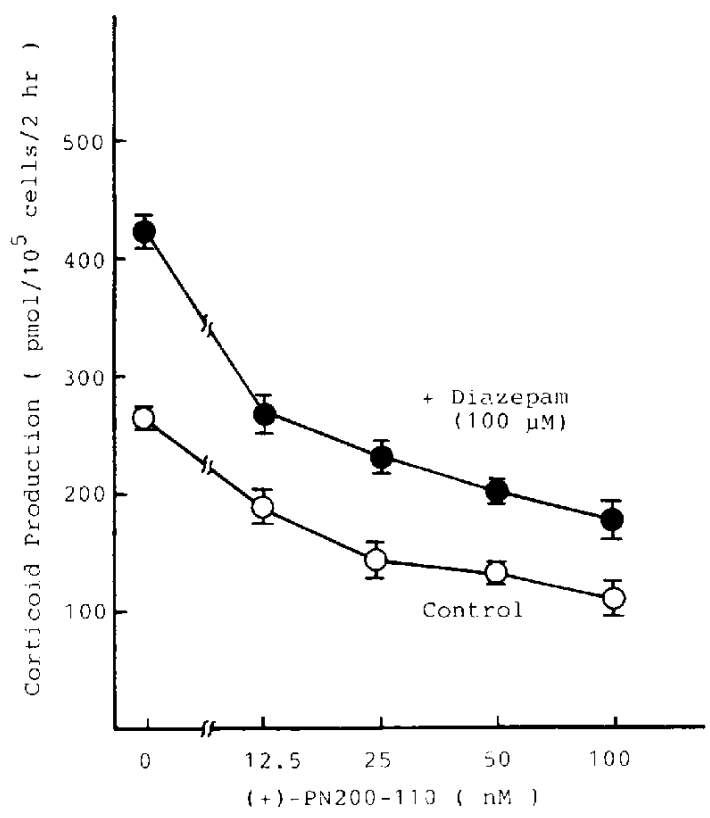

Fig. 7. Effect of (+)-PN200-110 on the potentiating effect of diazepam during corticoidogenic

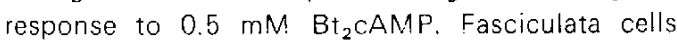
were preincubated at $37^{\circ} \mathrm{C}$ for $10 \mathrm{~min}$ with (O) or without (O) diazepam (100 $\mu \mathrm{M})$ and (+)-PN200110 (indicated concentrations), and the reaction was started by adding $0.5 \mathrm{mM} \mathrm{Bt}{ }_{2}$ CAMP. After a $2 \mathrm{hr}$ incubation, corticoids were extracted with dichloromethane from the cell suspensions and estimated fluorometrically. Each value represents the mean \pm S.E. of triplicate determinations of two separate experiments

cells, but the increased concentration of celIular cyclic AMP is one-thousand fold less than that by $\mathrm{Bt}_{2} \mathrm{CAM} P$ used in the present study (20). Thus, the stimulatory mechanism of exogenously added $\mathrm{Bt}_{2} \mathrm{CAMP}$ on corticoidogenesis might be different from those of $\mathrm{ACTH}$ and $\mathrm{KCl}$.

In an attempt to elucidate the mechanism of action of diazepam on the potentiating effect, the intracellular cholesterol dynamics under the corticoidogenic response to $\mathrm{Bt}_{2}-$ CAMP plus diazepam were observed. We have purified a novel protein termed des-endozepine whose synthesis is tightly coupled to acute adrenal steroidogenesis (15, 16). (K. Yanagibashi et al., unpublished data). This protein appears to bind to the adrenal peripheral type benzodiazepine receptor (30) 
and stimulate cholesterol delivery to the inner mitochondrial membrane (15). Studies are now being undertaken in this laboratory to determine the precise mechanism of desendozepine on cholesterol mobilization and also the interrelation between this protein and benzodiazepines. Our results shown in Figs. 4 and 6 suggest that the potentiating effect of diazepam is due in part to the activation of the intracellular cholesterol supply system (cholesterol de novo synthesis). This is in good agreement with the results reported by Sekimoto et al. (31) that the corticoidogenic action of $\mathrm{Bt}_{2} \mathrm{CAMP}$ in bovine adrenal fasciculata cells is mediated by the activation of cholesterylester hydrolase, and the derived free cholesterol from the cholesteryl esters is one of the essential sources for the substrate of corticoidogenesis within the 90 min-incubation. By contrast, it is likely that the activation of cholesterol de novo synthesis is a possible site of the potentiating action of diazepam (Fig. 6).

In order to determine whether or not the potentiating action of diazepam is mediated bv a specific interaction with benzodiazepine receptors, we evaluated the effect of the diazepam antagonist YM-684 (Ro 15-1788) on the diazepam-induced potentiation. As shown in Fig. 5, the potentiating effect of diazepam is inhibited by $Y M-684$ in a concentration range $(\approx \mu M)$ that is consistent with its pharmacological effect on the rat hippocampal slice $(32,33)$. These results suggest that the antagonist not only binds to the central type receptor with high affinity but may also intreract less strongly or nonselectively with the peripheral type receptor $(23,34)$.

The present experiments indicate that a possible role of peripheral type benzodiazepine receptors on the corticoidogenic response to $B t_{2}$ CAMP is in the activation steps of the intacellular cholesterol supply system without any functional coupling to voltagedependent calcium channels.

Acknowledgment: The authors wish to thank Miss Chieko Gidou for her excellent technical assistance.

\section{References}

1 Braestrup, C. and Squires, R.F.: Specific benzodiazepine receptors in rat brain characterized by high-affinity $\left[{ }^{3} \mathrm{H}\right]$-diazepam binding. Proc. Natl. Acad. Sci. U.S.A. 74, 3805-3809 (1977)

2 Möhler, H. and Okada, T.C.: Benzodiazepine receptor: Demonstration in the central nervous system. Science 198, 849-851 (1977)

3 Tallman, J.F., Thomas, Y.J. and Gallager, D.W.: GABAergic modulation of benzodiazepine binding site sensitivity. Nature 274, 383-385 (1978)

4 Tallman, J.F., Paul, S.M., Skolnick, P, and Gallager, D.W.: Receptors for the age of anxiety: Pharmacology of the benzodiazepines. Science 207, 274-281 (1980)

5 Olsen, R.W.: GABA-benzodiazepine-barbiturate receptor interactions. J. Neurochem. 31, 1-13 (1981)

6 Sigel, E., Stephenson, F.A., Mamalaki, C. and Barnard, E.: A $\gamma$-aminobutyric acid/benzodiazepine receptor complex of bovine cerebral cortex: Purification and partial characterization. J. Biol. Chem. 258, 6965-6971 (1983)

7 Sigel, E. and Barnard, E.A.: A $\gamma$-aminobutyric acid/benzodiazepine receptor complex from bovine cerebral cortex: improved purification with preservation of regulatory sites and their interactions. J. Biol. Chem. 259, 7219-7223 (1984)

8 Schofield, P.R., Darlison, M.G., Fujita, N., Burt, D.R., Stephenson, F.A., Rodriguez, H., Rhee, L.M., Ramachandran, J., Reale, V., Glencorse, T., Seeburg, P.H. and Barnard, E.A.: Sequence and functional expression of the GABAA receptor shows a ligand-gated receptor super-family. Nature 328, 221-227 (1987)

9 Marangos, P.J., Patel, J., Boulenger, J.-P. and Clark-Rosenberg, R.: Characterization of peripheral-type benzodiazepine binding sites in brain using $\left[{ }^{3} \mathrm{H}\right]-\mathrm{Ro}$ 5-4864. Mol. Pharmacol. 22, 26-32 (1982)

10 Schoemaker, H., Boles, R.G., Horst, W.D. and Yamamura, H.I.: Specific high-affinity binding sites for $\left[{ }^{3} \mathrm{H}\right]$ Ro $5-4864$ in rat brain and kidney J. Pharmacol. Exp. Ther. 225, 61-69 (1983)

11 Le Fur, G., Perrier, M.L., Vaucher, N., Imbault, F., Flamier, A., Benavides, J., Uzan, A., Renault, C., Dubroeucq, M.C. and Guérémy, C.: Peripheral benzodiazepine binding sites: Effect of PK11195, 1 - (2 - chlorophenyl) - N-methyl - N - (1 - methylpropyl)-3-isoquinolinecarboxamide. I. In vitro studies. Life Sci. 32, 1839-1847 (1983)

12 Le Fur, G., Guilloux, F., Rufat, P., Benavides, J.. Uzan, A., Ranault, C., Dubroeucq, M. C. and Guérémy, C.: Peripheral benzodiazepine binding 
sites: Effect of PK11195, 1-(2-chlorophenyl)-Nmethyl-(1 - methylpropyl) - 3 -isoquinolinecarboxamide. Il. In vivo studies. Life Sci. 32, 1849-1856 (1983)

13 De Souza, E.B., Anholt, R.R.H., Murphy, K.H.H., Snyder, S.H. and Kuhar, M.J.: Peripheral-type benzodiazepine receptors in endocrine organs: Autoradiographic localization in rat pitultary. adrenal, and testis. Endocrinology 116, 567-573 (1985)

14 Shibata, H., Kojima, I. and Ogata, E.: Diazepam inhibits potassium-induced aldosterone secretion in adrenal glomerulosa cell. Biochem. Biophys. Res. Commun. 135, 994-999 (1986)

15 Yanagibashi, K., Ohno, Y., Kawamura, M. and Hall, P.F.: The regulation of intracellular transport of cholesterol in bovine adrenal cells: Purification of a novel protein. Endocrinology 123, 20752082 (1988)

16 Hall, P.F., Papadopoulos, $V$. and Yanagibashi, K.: On the mechanism of action of ACTH. In Progress in Endocrinology. Edited by Imura, H., Shizume, K. and Yoshida, S., p. 253-258. Excerpta Medica, Amsterdam (1988)

17 Marquardt, H., Todaro, G.J. and Shoyab, M.: Complete amino acid seauences of bovine and human endozepines: Homology with rat diazepam binding inhibitor. J. Biol. Chem. 261 , 9727-9731 (1986)

18 Besman, M.J., Yanagibashi, K., Lee, T.D., Kawamura, M., Hall, P.F. and Shively, J.E.: Identification of des-(Gly-lle)-endozepine as an effector of corticotropin-dependent adrenal steroidogenesis: Stimulation of cholesterol delivery is mediated by the peripheral benzodiazepine receptor. Proc. Natl. Acad. Sci. U.S.A. 86, $4897-$ 4901 (1989)

19 Yanagibashi, K., Kamiya, N., Lin, G. and Matsuba, M.: Studies on adrenocorticotropic hormone receptor using isolated rat adrenocortical cells. Endocrinol. Japon. 25, 545-551 (1978)

20 Yanagibashi, K., Papadopoulos, V., Masaki, E., Iwaki, T., Kawamura, M. and Hall, P.F.: Forskolin activates voltage-dependent $\mathrm{Ca}^{2+}$ channels in bovine but not in rat adrenal fasciculata cells. Endocrinology 124, 2383-2391 (1989)

21 Silber, R.H., Bush, R.D. and Oslapas, R.: Practical procedure for estimation of corticosterone and hydrocortisone. Clin. Chem. 4, 278285 (1958)

22 Gamble, E., Vaughan, M., Kruth, H.S, and Avigan, J.: Procedure for determination of free and total cholesterol in micro- or nanogram amounts suitable for studies with cultured cell. J. Lipid Res. 19, 1068-1070 (1978)
23 Hunkeler, W., Möhler, H., Pieri, L., Polc, P., Bonetti, E.P., Cumin, R., Schaffner, R. and Haefely, W.: Selective antagonists of benzodiazepines. Nature 290, 514-516 (1981)

24 Endo, A., Kuroda, M. and Tanzawa, K.: Compe. titive inhibition of 3-methylglutaryl coenzyme $A$ reductase by $M L-236 \mathrm{~A}$ and $\mathrm{ML}-236 \mathrm{~B}$ fungal metabolites, having hypocholesterolemic activity. FEBS Lett. 72, 323-326 (1976)

25 Cognard, C., Romey, G., Galizzi, J.-P., Fosset, M. and Lazdunski, M.: Dihydropyridine-sensitive $\mathrm{Ca}^{2+}$ channels in mammalian skeletal muscle cells in culture: Electrophysiological properties and interactions with $\mathrm{Ca}^{2+}$ channel activator (Bay K8644) and inhibitor (PN200-110). Proc. Natl. Acad. Sci. U.S.A. 83, 1518-1522 (1986)

26 Weissmann, B.A., Cott, J., Hommer, D., Quirion, R., Paul, S. and Skolnik, P.: Benzodiazepine recognition site ligands. In Biochemistry and Pharmacology. Edited by Biggio. G. and Costa, E.. p. 139-151, Raven Press, New York (1983)

27 Cantor, E.H., Kenessey, A., Semenuk, G. and Spector, S: Interaction of calcium channel blockers with non-neuronal benzodiazepine binding sites. Proc. Natl. Acad. Sci. U.S.A. 81 , 1549-1552 (1984)

28 Mestre, M., Carriot, T., Belin, C., Uzan, A., Renault, C., Dubroeucq, M.C., Guérémy, $C$.r Doble, A. and Le Fur, G.: Electrophysiological and pharmacological evidence that peripheral type benzodiazepine receptors are coupled to calcium channels in the heart. Life Sci. 36, 391400 (1985)

29 Bender, A.S. and Hertz, L.: Pharmacological evidence that the non-neuronal diazepam binding site in primary cultures of glial cells is associated with a calcium channel. Eur. J. Pharmacol. 110, 287-288 (1985)

30 Alho, H., Fremeau, R.T., Jr., Tiedge, H., Wilcox, J., Bovolin, P., Brosius, J., Roberts, J.L. and Costa, E.: Diazepam binding inhibitor gene expression: Location in brain and peripheral tissues of rat. Proc. Natl. Acad. Sci. U.S.A. 85, 7018$7022(1988)$

31 Sekimoto, T., Tanaka, Y., Imagawa, N., Tomita, C. and Matsuba, M.: Possible involvement of $\mathrm{Ca}^{2+}$-calmodulin system in cyclic $\triangle M P$ action in cholesterol ester hydrolytic response to $\mathrm{ACTH}$ in bovine adrenocortical cells. Endocrinol. Japon. 31, 283-289 (1984)

32 King, G.L., Knox, J.J. and Dingledine, R.: Reduction of inhibition by a benzodiazepine antagonist, Ro 15-1788, in the rat hippocampal slice. Neuroscience 15, 371-378 (1985)

33 Stone, T.W.: The suppression of hippocampal 
potentials by the benzodiazepine antagonist Ro $15-1788$ may be mediated by purines. Brain Res. 380, 379-382 (1986)
34 Nutt, D.J., Cowen, P.J. and Little, H.J.: Unusual interactions of benzodiazepine receptor antagonists. Nature 295, 436-438 (1982) 